\title{
Dusjing i sjukeheim Eit historisk og notidig perspektiv
}

\author{
Jeanne Helene Boge \\ Fyrsteamanuensis i sjukepleie, Institutt for sykepleiefag/Senter for omsorgsforskning Vest, Høgskulen på \\ Vestlandet
}

jhb@hvl.no

\section{Sammendrag}

Bebuarar i sjukeheim kan vere misnøgde med å skulle dusje kvar 14. dag. Misnøya kan ha samband med at norske menn og kvinner tradisjonelt har vaska heile kroppen ekstra godt ein gong i veka. Kroppsvask kvar 14. dag er eit brot med slike praksisar. Misnøya kan også ha samband med at bebuarane i studien, som alle var fødde i perioden 1915 - 1935, vaks opp i eit samfunn der dusj var uvanleg. Så seint som i 1959 var det berre 18 \% av norske bustader som hadde baderom. På den tida brukte folk flest i Noreg eit vaskefat og ein klut når dei skulle vaske heile kroppen, og det blei vanlegvis gjort på laurdagen. Barn kunne bli vaska i ein stamp til helga, og nokre av bebuarane som blei intervjua i sjukeheimen føretrekte full kroppsvask i badekar i staden for dusj, men det var ikkje mogeleg fordi det ikkje var badekar i sjukeheimen. Brot med etablerte praksisar kan vere spesielt utfordrande for bebuarar med demenslidingar, noko over $80 \%$ av bebuarane i norske sjukeheimar har. Menneske med kognitiv svikt har det gjerne best når dei får halde fram med etablerte praksisar.

Data om korleis full kroppsvask blei gjort og erfart blei generert ved hjelp av intervju med åtte pleietrengjande og 10 hjelpepleiarar i ein norsk sjukeheim. Lærebøker i sjukepleie, sosiologiske -, etnografiske - og historiske kjelder om kroppsvask i eit historisk perspektiv har blitt brukt som underlag for å forklare bebuarane og pleiarane sine erfaringar med dusjpraksisane i sjukeheimen. Teoretisk er artikkelen fundert i Pierre Bourdieu sin teori om habitus. Habitus handlar om korleis dei historiske og notidige sosiale strukturane vert inkorporert som uartikulerte, umedvitne haldningar som er felles for dei som har levd i den same samfunnskonteksten. Å forklare notida ved hjelp av fortida har lange tradisjonar i fransk historisk epistemologi.

Nøkkelord: dusj, sjukeheim, demens, habitus, historisk, Bourdieu, kroppsvask, hygiene, sjukepleie.

Publisert: 01.01.2019

Praxeologi - Et kritisk refleksivt blikk på sosiale praktikker @2019 Jeanne H. Boge

Dette er en open access-artikkel distribuert under vilkårene i lisensen Creative Commons Navngivelse (CC-BY 4.0) DOI: http://dx.doi.org/10.15845/praxeologi.v1i0.1396 


\section{Abstract}

Residents in Norwegian nursing homes can dislike having showers every fortnight. The discontent can be due to Norwegian's long lasting traditions on washing the body extra well once a week. A full body wash every 14 th day represents a break with such weekly practices. The discontent can also be due to the fact that the residents, that were all born between 1915 and 1935, grew up at a time when showers were uncommon. As late as in 1959, only $18 \%$ of Norwegian households had a bathroom. At that time, people usually used a washbasin and a face cloth for washing the whole body, which one usually did on Saturdays. Children could be washed in a tub. Thus, some of the residents preferred to have a full body wash in a bath, not a shower. That, however, was not possible because there were no bath tubs in the nursing homes. Practices that break with established habits can be especially challenging for residents with dementia, and more than $80 \%$ of residents in Norwegian nursing homes suffer from dementia. People with a cognitive decline usually function best when they can live in accordance with established habits.

The data on body washing in a contemporary Norwegian nursing home were based on interviews with eight residents and 10 auxiliary nurses. Textbooks in nursing, as well as sociological -, ethnographic - and historic texts on cleanliness were used to explain the residents' and the staff's experiences with the bodily washing practices in the nursing home. Theoretically, the article is based on Pierre Bourdieu's theory on habitus; a theory on how practices are being incorporated as inarticulate, unconscious attitudes that are the same for those who have grown up and lived in similar contexts.

Key words: Shower, nursing home, dementia, habitus, historical, Bourdieu, body wash, hygiene, nursing.

\section{Innleiing}

Denne artikkelen handlar om tilhøvet mellom dusjpraksisar i ein norsk sjukeheim og fullkroppsvaskinga som var vanleg då bebuarane vaks opp. Bakgrunnen for studien er tidlegare studiar som viser at eldre pleietrengjande kan vere misnøgde med den kroppslege vaskinga som dei får tilbod om i helsevesenet fordi praksisane bryt med dei etablerte vaskevanane deira. For pleietrengjande med kognitiv svikt kan slike brot vere spesielt uheldige, avdi desse pleietrengjande ofte har det best når dei får halde fram med praksisar som dei har vore vande med. Over $80 \% \mathrm{av}$ bebuarane i sjukeheim har kognitiv svikt (Regjeringen, 2015, s. 18).

I denne artikkelen vert det argumentert for at bebuarar si misnøye med dusjpraksisar i sjukeheim kan forklarast i lys av vaskevanane som dei vaks opp med. Det empiriske grunnlaget for artikkelen er intervju med åtte bebuarar og ti pleiarar i sjukeheim om korleis kroppsvask vert gjort og erfart. Analysar av lærebøker i sjukepleie, samt sosiologiske, etnografiske og historiske kjelder om kroppsvask er brukt som underlag for å forklare bebuarane og pleiarane sine erfaringar med dei kroppslege vaskepraksisane. Teoretisk er artikkelen fundert i Pierre Bourdieus teori om habitus. Det vil seie ein teori om korleis dei historiske og notidige strukturane som ein veks opp i/lever i, vert inkorporerte i individa som uartikulerte, umedvitne haldningar som er felles for dei som har levd $\mathrm{i}$ den same samfunnskontekst. Å forklare notida ved hjelp av fortida har lange tradisjonar i fransk historisk epistemologi (Bourdieu, 1973, s. 72-108; Callewaert, 1997, 133 - 138).

Formålet med artikkelen er ikkje å moralisere eller å generere retningslinjer for korleis pleietrengjande i sjukeheimar bør vaskast, men å forklare bebuarane sine erfaringar med dusjing, og såleis skape grunnlag for kroppslege vaskepraksisar som er i pakt med dei pleietrengjande sine etablerte kroppsvask-vanar. 


\section{Bakgrunn}

Kroppsvask vert gjort på ulike vis i ulike kulturar. Det blei tydeleg i nokre samtaler eg hadde med finske pleiarar som arbeidde i ein norsk sjukeheim våren 2017. Dei fortalde at dei ikkje hadde brukt vaskefat og klut ved kroppsvask i sjukeheimar i Finland. Der var det vanleg at alle bebuarane dusja kvar dag. Pleietrengjande som ikkje klarte å stå eller sitte oppreist, låg på ei dusjseng i slike høve. I Danmark er det ikkje snakk om dagleg dusj for pleietrengjande. Der drøftar dei om pleietrengjande bør ha rett på hjelp frå det offentlege til dusj to gonger i veka. Det har ikkje vore politisk vilje til å nedfelle ein slik rett (Hoffmann-Hansen, 2013). Noreg har heller ikkje dusjnormer i kommunale pleietenester, men Rådet for videregående opplæring har utarbeidd materiell som viser at det vert forventa at norske menn (Fjeld \& Olsen, 2000b) og kvinner (Fjeld \& Olsen, 2000a) dusjar kvar dag. Materialet er laga med støtte av Statens helsetilsyn. Som me skal sjå lenger framme i teksten, har norske lærebøker i sjukepleie også argumentert for dagleg full kroppsvask dei siste 50 åra.

Artikkelen tek utgangspunkt i vaskepraksisar i ein norsk sjukeheim. Slike institusjonar har eksistert i Noreg sidan midten av 1800-talet. På1960-talet blei det bygd ei rekkje nye sjukeheimar, slik at pleietrengjande eldre som låg på sjukehus, men ikkje trong medisinske intervensjonar, kunne flyttast ut av sjukehusa. På 1970-talet fann ein ut at det blei for kostbart å bygge sjukeheimar for alle pleietrengjande, og offentleg betalt heimesjukepleie blei etablert (Fæ $\varnothing, 2016)$. I dag er det berre dei mest pleietrengjande som får plass i sjukeheimar. 75,2 \% av bebuarane er 80 år eller eldre. Alderen har vore stigande og bebuarane har omfattande pleiebehov (Regjeringen, 2015). $97 \%$ treng hjelp i samband med kroppsvask (Hofseth \& Norvoll, 2003, s. 13 og 17). Sjukeheimsarbeid har låg status i det medisinske feltet (Album, 1999; Martinsen \& Wærness, 1991; Myking, 2013). Utdanningsnivået og pleiefaktoren er mykje lågare enn i spesialisthelsetenester og ufriviljug deltid er utbreidd (Jeanne Boge \& Petersen, 2016; Moland, 2013).

\section{Tidlegare studiar om kroppsvask i pleiesamanhengar}

Trass i det store omfanget av kroppspleie som dagleg vert utført i helsevesenet, er det relativt få studiar om kroppsvask. Det kan ha samband med den låge statusen slikt arbeid har og med tabu som er knytt til kropp i moderne samfunn (Lawler, 1996). Sjølv om det ikkje fløymer over av studiar om kroppsvask, så finst det forsking frå sjukehus som viser at det er viktig for sjuke og pleietrengjande å kjenna seg reine og velstelte (Boge 1999, Gregersen, 2002; Lomborg, Bjørn, Dahl, \& Kirkevold, 2005), men dei materielle fasilitetane kan gjere det vanskeleg å få vaska og stelt seg slik ein er vand med (Ugland, 1998).

Som tidlegare nemnt har over $80 \%$ av dei som bur fast i norske sjukeheimar kognitiv svikt (Regjeringen 2020, s. 18). Slike bebuarar kan det vere ekstra tidkrevjande å hjelpe i samband med kroppspleie. Ruth Olsen sin studie i sjukepleievitskap viser at eit vanleg morgonstell med bebuarar som hadde kognitiv svikt tok 35 minutt når det blei gjort i den pleietrengjande sitt tempo. Eit tilsvarande morgonstell der pleiaren utfører heile kroppsvasken for den pleietrengjande tok kring 20 minutt. Studien var basert på observasjon av korleis 17 pleiarar gjennomførte morgonstellet når bebuar hadde kognitiv svikt (Olsen, 1998, 50-71). Ein studie i sjukepleievitskap om kroppsvask i USA indikerer at personar med demens likte å bli vaska ved hjelp av handduksbad i staden for dusj. Studien, som omfatta 69 sjukeheimsbebuarar, viser at det ikkje tok lenger tid å gjennomføre vask av heile kroppen ved hjelp av handduksbad enn ved hjelp av dusj, men bebuarane var mykje meir tilfredse og mindre aggressive når det vart brukt handduksbad, det vil seie at bebuarane blei vaska ved hjelp av varme, fuktige handdukar som blei lagt på kroppen (Sloane, Hoeffer, Mitchell, \& al., 2004). I ein studien utført av den engelske sosiologen Lee Treweek (1997) blei det ikkje nytta 
handduksbad, og ho argumenterer for at presset på å laga reine, ordentlege, velluktande individ så raskt som mogeleg var overordna omsynet til den enkelte pleietrengjande sin tilstand og vanar.

Sosiologiske studiar frå heimebaserte tenester i England viser at dei eldre ynskjer å vere reine, men dei kan mislike at kroppsvasken vert gjennomført i form av dusj (Twigg, 2000, s. 32-44). Dei har vore vande med badekar og knytte karbad til velvere og nyting. Andre studiar derimot teiknar eit mindre eintydig bilete og syner at ein del av sjukeheimsbebuarane føretrekkjer dagleg dusj (Larsen, 1999, s. 7-8. 69-111). Pleietrengjande som hadde vore vande med å dusje dagleg, måtte slutte med det då dei blei avhengige av offentleg betalte pleiarar for å dusje. Pleiarane i heimesjukepleia hadde ikkje tid til å hjelpe dei pleietrengjande med å dusje oftare enn ein gong i veka. Av og til kunne det gå 14 dagar mellom kvar gong dusj blei gjennomført. Det var med andre ord kommuneøkonomien som avgjorde kor ofte pleietrengjande fekk hjelp til å dusje. Heller ikkje i studien Kroppsvask i sjukepleia (Boge 2008) var det rom for at dei pleietrengjande fekk halde fram med etablerte vanskevanar. Studien var basert på observasjonar og intervju i ein norsk sjukeheim. Denne artikkelen er basert på nye analysar av tilhøvet mellom dusjpraksisane i sistnemnde studie og fullkroppsvaskinga som var vanleg då dei intervjua bebuarane vaks opp. I analysane som vert presenterte lenger framme i teksten vil me sjå at både i fortid og notid har samfunnsøkonomiske tilhøve i samband med kroppsvask vore overordna innbyggjarane sine etablerte vaskevanar.

\section{Ei praxeologisk tilnærming}

Analysane er baserte på ein teori om at ein må forklare notidige dusjpraksisar og -erfaringar i ein sjukeheim i lys av oppkomsten til dusj. I tillegg må analysane omfatte undersøkingar av vaskepraksisane som dei eldre har vakse opp med og undersøkingar av sjukeheimskonteksten som dei bur i. Praxeologi inneber med andre ord både ei fenomenologisk tilnærming, der ein unders $\varnothing$ kjer korleis individa erfarer sosiale praksisar, og analyser av relasjonen mellom individa sine erfaringar og dei notidige og fortidige strukturane (Petersen \& Callewaert, 2013; Petersen, 1993). Å forklare notidige praksisar i lys av studiar av oppkomst har lange tradisjonar i fransk epistemologi og er basert på ein teori om at praksisane til dei som har levd før oss er inkorporert i habitusen vår (Bourdieu, 1973, s. 72-108; Callewaert, 1997, s. 133-38). Habitus er uartikulerte, umedvitne haldningar og handlingar som er felles for dei som har levd i dei same historiske og notidige samfunnskontekstar. Dei objektive strukturane vert indre strukturar som får oss til å forstå, tolke og handle på bestemde måtar. Habitusen som me har etablert i barndommen dannar i stor grad basis for korleis me tenkjer og handlar seinare i livet. Habitusen vert skapt i møtet mellom det individuelle erfaringane og dei objektive samfunnsstrukturane som ein vert fødd inn i og veks opp i (Halskov, Lundin, \& Petersen, 2008). Samstundes som habitusen til menneske som har vakse opp i same land har mange fellestrekk, så er den også ulik fordi individa som lever i det same landet og den same byen kan vekse opp i familiar med ulike sosiale, kulturelle og økonomiske kapitalar, det vil seie med ulike disposisjonar og tilhøyrande posisjonar, og dermed kan dei ha fått overført og påført ulike kroppslege vaskevanar, fordi, som me vil sjå lenger nede i teksten, har økonomi vore avgjerande for korleis kroppsvask har blitt gjort i moderne samfunn. I analysane av dusjpraksisane må ein også ta omsyn til at individa som er involverte i denne studien bur i sjukeheim, og majoriteten av bebuarane i slike institusjonar har demens. Det inneber at dei har store problem med å hugse det som nyleg har hendt og dei kan ha store problem med å ta inn nye praksisar, samstundes som dei kan hugse godt det som skjedde før dei fekk demens, derfor er det viktig å halde fast ved praksisar som dei vaks opp med. Dette er tydeleg i studiar om musikk og dans; bebuarar som mest har tapt evna til å snakke kan synge av full hals når dei høyrer songar som dei kunne godt i oppveksten, og enkelte som vanlegvis har store problem med å gå kan begynne å danse når dei høyrer kjende tonar. Den norske legen og musikkterapeuten Audun Myskja argumenterer for at den uventa synginga og dansinga har samband med at hjartet hugsar det hovudet har gløymt (Myskja, 2017). I staden for å seie at hjartet hugsar, vil 
Bourdieu seie at kroppen hugsar (Pierre Bourdieu, 1973, s. 72-108), men både Myskja og Bourdieu argumenterer for at fortida lever med individa i notida.

\section{Forskingsteknikkar}

Denne artikkelen er hovudsakleg basert på analysar av eit materiale om kroppsvask som blei generert i ein norsk sjukeheim i 2002 og 2006, på analysar av lærebøker i sjukepleie og på sosiologiske, etnografiske og historiske kjelder.

\section{Analyse av historiske kjelder}

Analysar av oppkomsten til notidige dusjpraksisar er hovudsakleg basert på lærebøker i sjukepleie og på sosiologiske, etnografiske og historiske kjelder (Kropp, 2009).

\section{Kjelder om kroppslege vaskenormer i sjukepleiefaget}

Lærebøker i sjukepleie frå ulike tidsepokar kan gje oss kunnskap om korleis sjukepleiefaget har tenkt at pleietrengjande sine kroppar bør vaskast. Sjølv om denne artikkelen hovudsakleg er basert på norske lærebøker i sjukepleie, er det også gjort analysar av Notater om sjukepleie av Florence Nightingale frå 1860 (Nightingale, 1997/1860), fordi dette var verdas fyrste lærebok i sjukepleie og den einaste som var tilgjengeleg då norsk sjukepleieutdanning blei oppretta i 1868 (Martinsen, 1984). Lærebøker i sjukepleie er normative kjelder og uttrykkjer sjukepleiefaget sine idear om korleis kroppen $b ø r$ vaskast. Slike kjelder seier ikkje noko om korleis kroppen faktisk blei vaska. Den fyrste norske læreboka i sjukepleie kom ut i 1877 (Nissen, 2000/1877). I 1911 kom det ut ei lærebok som argumenterte for kroppsvask på ein annan måte enn Nissen hadde gjort (Waage, 1911), men det var fyrst i 1967 at det kom ut ei lærebok som argumenterte for dusj (Lerheim \& sykepleierforbund, 1967). For å kaste lys over normene for kroppsvask som var gjeldande i sjukepleiefaget då intervjua $\mathrm{i}$ denne studien vart gjennomført, er det gjort analysar av ei av dei mest brukte lærebøkene på den tida, Generell sykepleie (Kristoffersen, 2004/1996). Kapittelet som omhandla kroppsvask var forfatta forskings - og fagutviklings sjukepleiar Aud Jorunn. Fylgjande spørsmål har blitt stilt til lærebøker i sjukepleie: Korleis bør pleietrengjande vaske seg?

\section{Kjelder om oppkomsten til moderne vaskenormer generelt, og dusj spesielt}

For å få kunnskap om korleis kroppsvask faktisk har blitt gjort til ulike tider og i ulike politiske kontekstar, er Eilert Sundt sin studie frå 1869 om reinsemd brukt som empirisk materiale om overgangen frå førmoderne til moderne kroppsvask i Noreg (Sundt, 1975/1869). Sundt vert rekna som Noregs fyrste sosiolog. Tilsvarande overgangar er skildra i historikaren Georges Vigarello sin studie om reinsemd i Paris (Vigarello, 1988), etnologen Jonas Frykmann sine studiar om reinsemd $\mathrm{i}$ Sverige (Frykman, 1994) og sosiologen Norbert Elias sine studiar om sivilisering i Nord-Europa (Elias, 1989/1939). Det er spesielt Vigarello sin studie som forklarer oppkomsten av dusj i Europa, medan ein norsk kulturhistorisk studie (Dæhlie, 2006), ein idrettspsykologisk studie (Augestad, 2005), ein studie om badeinnretningar i arbeidarbustader (Johnsen, 2004), fleire tekstar som museum i Bergen har utgitt om reinsemd (Lundström, Hermansen, \& Kellmer, 1978; Økland \& Høiaas, 2000) og ein studie om kroppsvask i Trøndelag i perioden 1900 - 1990 (Selseth, 1995) kastar lys over dusjen sin oppkomst i Noreg. 


\section{Analyser av data om dusjpraksisar i ein norsk sjukeheim}

Data om korleis dusj vert gjort og erfart er basert på intervju med 8 bebuarar og 10 pleiarar i ein norsk sjukeheim ${ }^{1}$. Intervjua blei gjennomført i 2002 og 2006 i samband med ein studie om kroppsvask (Boge, 2008). Bebuarane som var inkluderte var fødde i perioden 1915-1935. Som vist lenger nede i teksten var det berre nokre få velståande som hadde bad i husa sine på den tida. Sjølv om det er sparsamt med bakgrunnsdata om bebuarane, er det lite som taler for at dei høyrde til i $\emptyset$ vre sosiale lag. Ingen av dei hadde utdanning på høgskule- eller universitetsnivå, ingen av dei hadde hatt leiande posisjonar og sjukeheimen dei budde i var plassert i ein bydel det tradisjonelt har budd folk med lite kulturell og økonomisk kapital. Bebuarane vaks opp i eit av Europas fattigaste land og det var stor ulikskap i levekår mellom folk flest og dei få som var rike (Schiøtz, 2003, s. 187-199). Det var høgst uvanleg at ålmugen hadde utdanning ut over folkeskulen då dei inkluderte bebuarane vaks opp. Det var fyrst i velferdsstaten som blei etablert i Noreg i etterkrigstida at det blei lagt til rette for at dei som ikkje hadde velståande foreldre kunne ta høgare utdanning (Bourdieu \& Passeron, 1999).

I tillegg til intervju med pleietrengjande, blei 10 hjelpepleiarar intervjua. Majoriteten hadde arbeidd 10-25 år med kroppspleie i sjukeheim, og dei var mellom 30 og 56 år. Pleiarane hadde vakse opp i ei tid då baderom med tilhøyrande sanitære fasilitetar blei norma i norske nybygg (Johnsen, 2004; Selseth, 1995). I studien om kroppsvask (Boge, 2008) blei det også gjort observasjonar av kroppsvask i samband med morgonstell, men denne artikkelen inneheld berre i liten grad observasjonsdata.

Som nemnt ovanfor har majoriteten av bebuarane i norske sjukeheimar kognitiv svikt, og sidan det kan vere vanskeleg å føre adekvate samtaler med personar som har slike utfordringar, blei dei med kognitiv svikt ekskluderte frå studien. Bebuarane som blei intervjua var fysisk svekka og ingen av dei klarte å dusje utan hjelp frå ein pleiar. Desse kan sjølvsagt ikkje representere alle bebuarar i sjukeheim, men det dei sa viser at dusjpraksisane i den aktuelle sjukeheimen var eit brot med vaskevanane dei hadde hatt $f \varnothing r$ dei flytta til sjukeheimen, og det likte dei ikkje. Slike brot vil truleg vere endå meir utfordrande for bebuarar med demens (Myskja, 2017; Regjeringen 2015).

Artikkelen kan kritiserast for å basere seg på gamle data, men eit feltabeid om toalettpraksisar $\mathrm{i}$ norske sjukeheimar som blei gjennomført i 2013 og som omfatta observasjonar av morgonstell viser at materialet om kroppsleg pleie frå 2002-2006 framleis er like aktuelt (Boge, Callewaert, \& Petersen, 2017). Fylgjande spørsmål blei stilt til dei transkriberte intervjua:

Kor ofte og når får bebuarar hjelp til å vaske heile kroppen?

Korleis vert full kroppsvask utført?

Korleis erfarast dusjpraksisane?

Nedanfor presenterer me fyrst resultata frå analysane av kjelder om oppkomsten til moderne vaskenormer generelt, og dusj spesielt. Deretter er det ein presentasjon av resultata frå analysane av intervju.

\section{Den historiske oppkomsten til notidige dusjnormer og -praksisar}

Studien er basert på ein teori om at dei personlege vaskevanane som den enkelte sjukeheimsbebuar har etablert i heimen ikkje berre er private, men også ei inkorporering av dei politiske tilhøva som dei kroppslege vaskepraksisane fann stad i (Bourdieu, 1973, s. 72-108; Callewaert, 1997, s. 133-38). For å

\footnotetext{
${ }^{1}$ Studien var godkjend av REK III (034.02).
} 
tydeleggjere den politiske dimensjonen ved kroppsvask, startar me med vaskepraksisar i mellomalderen og viser korleis dei endra seg i moderne samfunn.

\section{Førmoderne vaskepraksisar}

I fylgje Eilert Sundt (1975/1868, s. 313-320) finst det teikningar frå mellomalderen av menn og kvinner som bada saman i badekar samstundes som dei blei traktert med musikk. På den tida sjenerte ein seg ikkje for å bade naken saman med andre i private eller offentlege badstover. For å spare brensel og arbeid var det gjerne slik at både unge og gamle i ei bygd bada saman. I fylgje Sundt liknar det me veit om badstover i Noreg i mellomalderen mykje på badstovepraksisane i Tyskland. Der var badstovene mykje vitja stader og bada var gjerne kombinerte med selskapleg underhaldning, samtaler, song og spel. Slik var det også i Paris i mellomalderen (Vigarello, 1988, 21-38). Det utarta ofte til overdådige og lystige samkomer med seksuelle utskeiingar. Dei bada ikkje for hygienen sin del men for velveret sin del.

Mot slutten av mellomalderen ville makthavarane ha slutt på det vellystige badelivet. Seksualitet skulle avgrensast til det som var nødvendig for reproduksjonen sin del (Elias, 1989/1939, s. 261-295; Foucault, 1995/1976, s. 62-86). I den samanheng blei det argumentert for at bad var farleg fordi vatnet kunne trengje inn i kroppen og forårsake ei rekkje alvorlege sjukdommar. Ingen ting er så effektivt som å truge med sjukdom, og i 1692 var det berre nokre få offentlege bad att i Paris. Folk ble forsiktige med vatnet (Vigarello, 1988, s. 9-48). Studien til Eilert Sundt om reinsemd i Noreg på 1860-talet viser at full kroppsvask gjerne var avgrensa til julehøgtida i Noreg på den tida. Til dagleg var det lite vasking, men til helga skulle synlege kroppsdelar som hender, andlet, hår og hals vanlegvis vaskast (Sundt, 1975/1869, s. 290-327). Dette var ikkje uttrykk for at norske menn og kvinner var spesielt ureinslege. Dei var minst like forsiktige med vatn i Sverige (Frykman 1994), England (Nightingale, 1997/1860) og i Frankrike (Vigarello, 1988).

\section{Moderne vaskepraksisar}

Redsla for vatnet varte ved i fleire hundre år, men i samband med moderniseringa, industrialiseringa og demokratiseringa av vestlege land i siste halvdel av 1800-talet blei det sett i verk eit storstilt politisk arbeid for å få folk flest til å vaske seg meir. På denne tida blei det argumentert for at kroppsvask var viktig for helsa sin del og at ein kunne bli sjuk, ja, til og med spedalsk, om ein ikkje var nøye med kroppsvasken (Christophersen, 1975, s. IX). Den internasjonale rørsla, Sanitation Movement, som starta i England, fekk ein sentral plass i det hygieniske reformarbeidet. Florence Nightingale var ein sentral aktør i denne hygienerørsla som mellom anna arbeidde for reint vatn, fjerning av avfall, større avstand mellom husa, lyse, reine og luftige bustader, kroppsleg reinsemd og helselover (Sydnes, 2001, s. 88 - 90). Nightingale hadde ein ide om at moderne sjukepleie, som ho etablerte i 1860, skulle bli sentrale i det moderne hygieneprosjektet, og slik blei det det (Wolf, 1993). Nightingale argumenterte for at sjølv om enkelte kunne oppleve det godt å bli vaska, var det overordna målet med kroppsvask ikkje velvere, men å reinse huda slik at den fekk puste. Å la vere å fjerne avfallsstoff kunne samanliknast med å gje pasienten seintverkane gift:

Enhver sykepleierske må alltid huske dette - for viss hun unnlater å vaske den syke, eller lar dem beholde klærne på etter at de er blitt innsatt med svette eller annet avfallsstoff, da blander hun seg skjebnesvangert inn i naturens helseprosess på en like effektiv måte som om hun hadde gitt pasienten en dose med sentvirkende gift gjennom munnen - det virker bare langsommere (...) lettelsen som den syke føler etter at huden er blitt grundig vasket og tørket, er en av de vanligste observasjoner man gjør ved en sykeseng. Men man må ikke glemme at velbehaget man oppnår, ikke er alt, det er bare et tegn på at livskreftene har fått ny styrke fordi det som hemmet dem er fjernet. (Nightingale 1997/1860, s. 136). 
Nightingale skriv ikkje noko om kor ofte ulike delar av kroppen bør reinsast. Det gjer derimot Rikke Nissen, som var redakt $\varnothing r$ for den fyrste norske lærebok i sjukepleie som kom ut i 1877 (Nissen, $2000 / 1877)$. Nissen skriv at heile kroppen bør vaskast ein gong i veka. I tillegg bør synlege kroppsdelar vaskast dagleg:

Den Syges Ansigt og Hænder maa daglig vaskes. (...) Den Syge maa, hvis han ikke er altfor svag, daglig skylle sin Mund. (...) Hver Dag bør i Regelen ogsaa Haaret redes.(...) En gang ugentlig vaskes Kroppen og Lemmerne, helst med en Svamp og lunkent Sæbevand, og tørres derpaa med et varmt Haandklæde. De Legemsdele, hvor Sved har samlet sig, maa især vaskes omhyggelig. (Nissen 2000/1877, s. 34).

At den vekentlege kroppsvasken også skulle omfatte delar av kroppen som var dekt til, var eit brot med den norske helgevasken som berre hadde omfatta synlege kroppsdelar (Sundt, 1975/1869, s. 290). Kroppsvasken som Nightingale og Nissen argumenterer for var i pakt med og ein lekk i arbeidet med å forme det moderne industrisamfunnet. I dette samfunnet trong ein friske, sterke, lydige, disiplinerte og produktive borgarar som ikkje gjorde opprør mot bedriftseigarar og andre makthavarar. Ideen var den at dei som var reine også var moralske og lydige, og i den samanheng blei det stort fokus på spesielt dei fattige si reinsemd, og det blei det sett i verk sanitære tiltak direkte retta mot fattigfolk. Dette er godt dokumentert i historikaren Vigarello sin studie om reinsemd i Paris (Vigarello, 1988, s. 191-198). Der blei det bygd offentlege bad og vaskeri på same stad kring 1850 for at dei fattige skulle få vanen med å byte og vaske klede samstundes som dei bada seg. Fattigfolk fekk ikkje bade meir enn 30 minutt, og dei fekk ikkje bruke mykje vatn. Det var innretta automatiske stoppekranar som slo inn når det var tilstrekkeleg vatn i badekaret. Det var eit tydeleg formulert mål å vaske flest mogeleg kroppar på kortast mogeleg tid, ved hjelp av minst mogeleg vatn. For at bada ikkje skulle bli for kostbare, var temperaturen regulert så lågt som forsvarleg. Etter kvart kom ein til at bad i badekar var for dyrt å gjera tilgjengeleg for fattigfolk. Dusj var billegare. Eksperimentet med dusj blei fyrst prøvd ut i fengsel, og etter 1880 blei slike innrettingar installert som offentlege badeinnrettingar i fattige bydelar i Paris. For at ein ikkje skulle vaske seg naken i andre sitt påsyn, vart det laga private dusjceller ved hjelp av forheng. Dusjinnrettingane som var rekna på massane stod $\mathrm{i}$ skarp kontrast til borgarskapet sine private baderom. For dei fattige var det ikkje snakk om større privat rom kring seg (Vigarello, 1988, s. 198-201).

Det er ikkje sikkert dusjar blei obligatoriske innrettingar i sjukehusa i Paris i siste halvdel av 1800 talet. Lærebøker i norsk sjukepleie indikerer i alle høve at dusj ikkje var vanleg på norske sjukehus på den tida, men i læreboka til Nissen vert behandlingsbad omtalt, noko som indikerer at det ikkje er uvanleg å ha badekar på sjukehusa i siste halvdel av 1800-talet, men det ser ikkje ut for at det er vanleg å bruke badekara i sjukehusa til ordinær kroppsvask, for Nissen skriv at full kroppsvask burde gjerast ved hjelp av ein svamp og lunka såpevatn når ein pasient kom inn på sjukehuset og elles ein gong i veka. Elles var det nok å vaske synlege kroppsdelar og eventuelle tilsølte delar av kroppen (Nissen, 2000/1877, s. 34, 53-58).

I 1911 får Noreg den fyrste læreboka i sjukepleie som argumenterte for at det ikkje er nok å vaske tildekte kroppsdelar ein gong i veka, men at det bør gjerast kvar dag: «De må hver dag vaskes paa sætet og ryggen. (...) Dessuten bør man daglig vaske saadanne dele av legemet hvor hud støter saman med hud; armhulerne, analregionen og skrævet, lyskerne og hos kvinder folderne under brystene.» (Waage, 1911, s. 82).

\section{Oppkomsten av dusj i Noreg}

I 1967 fekk norsk sjukepleie den fyrste læreboka som argumenterte for dusj: «Pasienten har krav på bad, evt. dusj, sengebad eller helvask en gang om dagen.» (Lerheim \& Norsk sykepleierforbund, 1967, s. 150). Argumentasjonen i læreboka frå 1967 er forståeleg i lys av det store arbeidet som blei 
sett i verk i etterkrigstida for at eit standard norsk hushald skulle ha innlagt vatn, elektrisk straum, toalett og baderom (Schiøtz, 2003, s. 410 - 13). I 1947 var det berre $6 \%$ av norske husvære som hadde bad (Augestad, 2005, s. 251-252; Selseth, 1995). På den tida var det vanlegvis berre rikmannsbustader som hadde baderom ( $\varnothing$ kland \& Høiaas, 2000). For å venja norske barn til å halde kroppane reine, trass i manglande vaskefasilitetar i heimane, blei det sett i verk eit storstilt arbeid for å utstyre skulane med bad i perioden 1925-1960, og det blei obligatorisk å dusje etter gymnastikk. I tillegg blei det bygd offentlege bad (Augestad, 2005; Johnsen, 2004, s. 158; Lundström et al., 1978). Så seint som i 1959 var det berre 18 \% av norske husvære som hadde bad. Full kroppsvask var vanlegvis avgrensa til laurdagen og den kunne bli gjennomført på kjøkkenet, i stova eller på soverommet ved hjelp av vaskefat og klut, medan barna kunne bade i ein stamp (Dæhlie, 2006, s. 95, 51-53). At det tok tid før bad blei allment tilgjengelege, er ikkje noko særnorsk fenomen. Sjølv om regelmessig vasking vart ein del av den daglege rutinen i middelklassen i USA frå 1850, og bad blei standard i middelklassehusa der kring 1900, var det fyrst etter den andre verdskrigen at bad blei vanleg i amerikanske og europeiske arbeidarklasseheimar, og det var fyrst etter 1980 at det blei vanleg at folk flest bada eller dusja oftare enn ein gong i veka. Det kosta å varme vatn (Twigg, 2000, s. 18-44, Johnsen 2004).

\section{Notidige dusjnormer i sjukepleia}

Som i læreboka til Lerheim og Norsk sykepleierforbund (1967) skriv den mest brukte læreboka i grunnleggjande sjukepleie i Noreg våren 2005 (Kristoffersen, 2004/1996) at det er vanleg å vaske heile kroppen kvar dag, og gjerne i form av dusj, og dette skriv forskings - og fagutviklingssjukepleiar Aud Jorunn Førsund som har forfatta den delen av læreboka som omhandlar kroppsvask: «Den ukentlige badedagen, laugardagen, er i dag erstattet med daglig dusj. Mange dusjer både morgen og kveld, etter endt arbeidsdag og/eller dagens trenings $\varnothing k t »$ (Førsund 2004/1996, s. 23). Samstundes argumenterer læreboka for at pleietrengjande bør få halda fram med etablerte vaskevanar: «I møte med medmennesker som trenger vår bistand, er det viktig å finne ut hva som har vært vanlig for vedkommende. Våre egne vaner trenger ikke være de eneste som tilfredsstiller dagens hygienekrav» (Førsund 2004/1996, s. 40). Dersom pasienten ikkje dusjar kvar dag bør håret vaskast når den pleietrengjande kjenner trong for det, men ikkje sjeldnare enn ein gong i veka: «Er pasienten bevisst, kjenner han ofte selv når hårvask er nødvendig. Håret må imidlertid vaskes en gang i uken» (Førsund, 2004, s. 79-80).

\section{Førebels oppsummering}

Kroppsvask er noko som har endra seg i pakt med politiske tilhøve elles i samfunnet, og dusj vart politisk interessant i samband med industrialiseringa og demokratiseringa av vestlege samfunn avdi det blei mogeleg å vaske mange menneske i offentlege bad til ein mykje lågare kostnad enn om dei vaska seg i badekar. Det var fyrst i etterkrigstida at folk flest fekk innlagt vatn og straum, og såleis høve til å bygge seg private baderom med varmt vatn. Dei som vaks opp før den tid hadde såleis ikkje vore vande med å dusje. Dei vaska seg ved hjelp av eit vaskefat og ein klut på soverommet, på kjøkkenet eller bak ei forheng i stova. Dette avspegla seg også i dei kroppslege vaskenormene som blei nedfelt i lærebøker i sjukepleie. Det var fyrst i etterkrigstida at samfunnstilhøva var slik at læreverka kunne argumentera for dusjing. 


\section{Dusj kvar 14. dag uavhengig av bebuarane sine etablerte vaskevanar}

Lærebøker i sjukepleie som var rådande i Noreg då intervjua i sjukeheimen blei gjennomført, argumenterer for at pleietrengjande må få halde fram med etablerte vaskevanar (Førsund 2004/1996, s. 40), men bebuarane i sjukeheimen måtte tilpasse seg til institusjonen si norm om dusj kvar 14. dag. Slike praksisar var ikkje vanlege då bebuarane som var fødde i perioden 1915-1935 vaks opp. Barn som vaks opp i Noreg utan bad hadde gjerne blitt bada i ein stamp til helga (Dæhlie, 2006, s. 96-99). Dei fleste av dei som budde i sjukeheimen hadde fått innlagt bad i godt vaksen alder, men det kan sjå ut for at dei ikkje brukte dusjen, men føretrekte å ta karbad når heile kroppen skulle vaskast, slik pleietrengjande i England også kunne føretrekkje (Twigg, 2000, s, 32-44). Slik nedsenking i vatn var i pakt med vaskevanane frå barndommen:

(...) eg var van til badekar heime, eg likar ikkje dusj (...) det er mange som ikkje likar dusj (...) dei er ikkje vande med det (...) eg tenkjer så masse på mor, (...) me var fem barn, og kvar laurdag måtte me opp i stampen, og då var ho så fel til å sutle med vatn, og mykje såpe. (Pleietrengjande 7, mann).

Det var ikkje mogeleg å få karbad i sjukeheimen. Tidlegare hadde sjukeheimen hatt eit badekar som 54 bebuarar delte, men pleiarane fortalde at dette var fjerna fordi logistikken blei vanskeleg når så mange skulle dele baderom og fordi det tok lang tid å fylle/tøme/vaske badekaret. Ein annan grunn skulle vere at mange ikkje likte å bade i badekaret. Det kan vere ulike grunnar for vegringa, men ein kan ikkje sjå bort i frå at bebuarar som var 50-60 år før dei fekk bad i husværet sitt hadde blitt så vande med å vaske seg ved hjelp av vaskefat og vaskeklut at dei heldt fram med det sjølv om dei hadde fått sine eigne baderom:

(...) det er dei pasientane som seier når den 14. dagen oppstår at dei gjer ikkje noko anna enn å dusje. Dei er av den gamle skulen som ikkje er vande med dusj heime, det var vaskefat og slikt, trur eg, no begynnar jo det og å endre seg. (Pleiar 4, kvinne).

Uavhengig av etablerte vaskevanar blei dusj vanlegvis gjennomført kvar 14. dag sjølv om bebuarane protesterte:

(...) det viser seg at dusj ein gong kvar 14.dag er meir enn nok for veldig mange. Dei er ikkje vande med det heller, og det er dei som prøver å sleppe unna å dusje (...) og då tvingar me dei $i$ bad. Me tvingar dei jo ikkje slik at dei skal, men me overtalar dei til å bli med på det (...) me vrir det til at det nok er det beste. (Pleiar 5, kvinne).

Pleiarane meinte det var greitt å presse bebuarane til dusj fordi mange gjerne gav uttrykk for at det var godt når det var gjort:

Det er ikkje alle som er så glade i å dusje (...) men etterpå seier dei (...) å, det var deilig (...) då kan du heller plage dei litt akkurat den tida, for etterpå så veit du at dei set pris på det likevel (...) sikkert fint å kjenne seg heilt rein. (Pleiar 6, mann).

Medan enkelte måtte pressast i dusjen kvar 14. dag, var det andre som ynskte å dusje oftare: «Til vanleg er det greitt å bli vaska (ved hjelp av vaskefat og klut), men det er deilig å få ein skikkeleg dusj og få vaska håret.» (Pleietrengjande 1, kvinne). Ho var den yngste bebuaren som vart intervjua, knapt 70 år då eg møtte henne i 2002, og ho hadde levd st $\varnothing$ rstedelen av livet sitt i eit samfunn der bad var blitt norm i norske bustader (Augestad, 2005; Johnsen, 2004; Selseth, 1995; Økland \& Høiaas, 2000). Denne kvinna hadde allereie budd i sjukeheimen i fleire år då eg møtte henne. Ho gav uttrykk for at ho hadde forståing for at det ikkje var mogeleg å få dusje oftare enn kvar 14. dag, for ho hadde sett at pleiarane hadde fått meir å gjera. Etter kvart var det blitt slik at dei både skulle ordne med 
frukost og vaske sengene når dei pleietrengjande dusja. Dette var oppgåver som anna personale hadde utført tidlegare. Trass i at ho forstod at praksisane var som dei var, tykte ho at dusj kvar 14. dag var altfor lite. Det velveret og behaget som fylgde med skulle ho gjerne hatt kvar veke:

Viss eg var heime så ville eg jo ha bada ein gong i veka, for det var eg jo vand med, om sommaren når eg sveitta mykje, så dusja eg jo gjerne oftare, elles så har eg ikkje vore noko overdrive dusjemenneske. Tykkjer det at huda må få behalda sitt naturlige feitt. Så når ein ikkje har eit spesielt fysisk tungt arbeid med mykje sveitte, så synest eg det held med ein gong i veka, så det kunne eg tenkt meg. (Pleietrengjande 4, kvinne).

Ei av dei andre bebuarane som også tykte det var altfor sjeldan å dusje annakvar veke, sa at ho måtte passe på at ho fekk dusje, elles så kunne det gå enda lenger tid mellom kvar gong:

(...) men så har me då kvar 14. dag (...) forferdeleg sjeldan (...) me får dusje (...) og derfor må me passa på at me får den 14. dagen (...) du må (...) passe på sjølv (...) dei kan begynne å krangla om at det ikkje er din dag i dag. (Pleietrengjande 3 , kvinne).

Pleiarane tykte dusj kvar 14. dag var for sjeldan. Det var leiinga som hadde avgjort kor ofte bebuarane skulle få dusje: «Det er innarbeidde rutinar .. det er frå huset si side ... dei dusjar ein gong kvar 14. dag» (pleiar 3, kvinne). Pleiarane hadde ingenting imot å dusje dei pleietrengjande. Det kunne rett og slett vera avslappande og kjekt å få vere åleine med bebuaren på badet, under føresetnad av at dei hadde med seg nok kvalifiserte pleiarar som kunne ta seg av dei andre oppgåvene i avdelinga. Problemet var at dei vanlegvis var to pleiarar på arbeid som hadde ansvar for ei gruppe med åtte bebuarar, og då blei dusj ei ekstra belastning, for dusj tok lenger tid enn den daglege vaskinga av nokre sentrale kroppsdelar ved hjelp av vaskefat og klut:

(...) eg tenkjer på kvar 14. dag når me har dusjveke. Då dusjar me to pasientar kvar dag, men når me dusjar to pasientar kvar dag, så har me seks andre (på gruppa) som ventar på å kome opp, så då spring me .. du kan seie, eg kan ikkje gje dei den tid dei treng (...) eg kan ikkje høyre alt dei seier. (Pleiar 2, mann).

Men dei hadde ikkje tid til å dusje alle kvar veke, for dusj tok lenger tid enn vask av enkelte kroppsdelar i seng:

(...) eg tykkjer jo det er veldig lite (med dusj kvar 14. dag) (...) men me har ikkje rom for meir (...) det tek lenger tid å dusje dei (...) då skal du skifte på senga, den skal vere rein, opp i heis, opp på badestol, kjøre inn på toalettet, opp igjen i heis, opp igjen i rullestol, tørke håret (...) eg må jo stelle tre, helst fire før frukost ... du har tre kvarter. (Pleiar 8, mann).

Observasjon av ein dusjsituasjon viste at det tok 85 minutt å dusje ei kvinne. I tillegg kom hårstell, tannpuss og sengereiing. Til samanlikning tok kroppsvask ved hjelp av vaskefat 15-45 minutt (Boge, 2008, s. 121). Den pleietrengjande som blei observert ved dusj var ikkje spesielt komplisert å dusje, ho kunne sitje på ein stol utan støtte medan pleiaren dusja henne. Andre var stive og ust $\varnothing$ dige, og då kunne dusjinga bli meir arbeidskrevjande, men dusj tok gjerne lengst tid når bebuarane hadde kognitiv svikt: «... det spelar ei rolle kor klare dei er ... ei som er lett på foten og lett å rettleie men (uklar), me må på ein måte stå der då.» (Pleiar 10, kvinne). "Vil anta at 80-85 prosent har nedsett mental kapasitet (...) men mange av dei har gjerne ikkje fått stilt diagnosen dement.» (Pleiar 9, mann). « (...) du må heile tida vegleia dei demente (...) det kan bli veldig tidkrevjande (...) for me har det utruleg travelt (...).» (Pleiar 2, mann)

Den pleietrengjande kvinna kring 70 år som hadde forståing for at det var blitt mindre tid til å dusje bebuarane (jf. ovanfor) fortalde at for nokre år sidan hadde ho fått vaska håret kvar veke, men dette var no redusert til hårvask kvar 14. dag i samband med dusj. Av og til kunne det gå bortimot tre 
veker mellom kvar gong ho dusja, og då gjekk det like lang tid før ho fekk vaska håret. Då vart håret svært feitt og ho kjende seg ustelt og uvel. Ho hadde fått beskjed om at ho måtte gå til frisør og sjølv betale dersom ho ville vaske håret oftare. Dette tykte ho var urimeleg, for om ho hadde budd heime ville ho sjølv ha vaska håret kvar veke. Frisør var ho berre van med å bruke når ho skulle klippe seg, farge håret eller ta permanent. Ho meinte det høyrde med til pleia å få vaska håret ein gong i veka, men dette var det ikkje rom for lenger:

Til å begynna med fekk eg vaska håret kvar veke (...) eg har feitt hår (...) eg meiner at det høyrer med til pleia (å vaske håret), så eg nekta å gå til frisørdama, og det gjer eg framleis (...) (går til frisør) viss eg skal klippe meg, ta permanent, eller farge eller noko slikt, (...) tingar eg frisør, for det er jo slik eg ville gjort (om eg var heime) (...) men eg går ikkje til frisør berre for å få vaska og lagt håret, for det høyrer med til pleia, dei skal stelle meg slik som eg ville stelt sjølv heime, og eg har alltid ordna håret mitt sjølv, og sett det opp med rullar (...) det vil eg ha her òg (...) men så kom der ein sjukepleiar (...) som var veldig bestemt på det at dei ikkje har tid til å halda på å vaske håret mitt kvar veke. (Pleietrengjande 4 , kvinne).

Dersom bebuarane gjekk til frisøren den veka dei ikkje dusja, ville håret bli vaska kvar veke: «Den eine veka er det gjerne slik at dei dusjar, krøllar og turkar håret i avdelinga, medan den andre veka er dei gjerne hjå frisør.» (Pleiar 9, mann). Men det viste seg at pleiarane gjerne innretta dusjdagen kvar 14. dag etter når frisøren hadde ledig tid, og så blei den pleietrengjande kjørt til frisøren for å stelle håret etter dusj. Dermed sparte pleiarane tid som dei elles måtte bruke til å vaske, rulle, føne, tørke og kjemme håret. Denne samkjøringa av dusj og frisør medførte at det gjekk 14 dagar mellom kvar gong håret blei vaska og stelt. Pleiarane tykte dusj med tilhøyrande hårvask kvar 14. dag var altfor sjeldan. Dei hadde ikkje klart å leve slik, men dei hadde ikkje tid til å dusje og vaske håret til alle bebuarane kvar veke.

At både bebuarar og pleiarar tykte dusj kvar 14. dag var for sjeldan kan ha samband med dei eldgamle norske vanane med omfattande kroppsvask om laurdagen (Sundt, 1975/1869). Sjølv om verken pleiarar og pleietrengjande forventa at bebuarane skulle få vaske heile kroppen om laurdagen, så tykte dei full kroppsvask kvar 14. dag var for sjeldan. Ein gong i veka såg ut for å vera eit minimum, og i ei av dei lærebøkene i grunnleggjande sjukepleie som var mest brukt då studien blei gjennomført vert det argumentert for at håret minimum må vaskast ein gong i veka (Førsund, 2004/1996, s. 79-80).

I sjukeheimar er løn til pleiarane den største utgiftsposten, og ved å la vere å dusje bebuarar oftare enn kvar 14. dag kan slike institusjonar spare pengar. Det er med andre ord $\varnothing$ konomiske omsyn som avgjer kor ofte bebuarane får dusje. Slik var det også den gongen dusj blei tatt i bruk på 1800-talet (Vigarello, 1988, s. 198-201). Dusj var mykje rimelegare for storsamfunnet enn at folk flest fekk bade seg regelmessig i badekar Avgjerda om at dei pleietrengjande i sjukeheimen heller ikkje fekk bade i badekar ser ut for å vere $\varnothing$ konomisk motivert. Sjølv om personalet argumenterte for at dei hadde teke vekk badekaret fordi dei eldre ikkje likte å bade, er det lite sannsynleg at det var derfor badekaret var fjerna, for dusj blei gjennomført sjølv om bebuarane ikkje likte det. Mangelen på badekar var ikkje spesielt for sjukeheimen i denne studien. I ein studie av baderom i 20 norske sjukeheimar i 2013 var det heller ikkje badekar (Boge, 2014; Boge et al., 2017). Det ser med andre ord ut for å vere få moglegheiter for å bade i badekar for norske menn og kvinner som flyttar $\mathrm{i}$ sjukeheim. Økonomiske omsyn ser ut for å gå framfor omsynet til dei pleietrengjande sine vaskevanar. Det var også økonomiske omsyn som var bakgrunnen for at danske styresmakter ikkje ville lovfeste pleietrengjande sin rett til dusj to gongar i veka og økonomi var også bakgrunnen for at norske pleietrengjande som var avhengig av heimesjukepleie for å dusje ikkje fekk halde fram med dusj kvar dag, sjølv om dei hadde vore vande med å gjere det (Larsen, 1999).

Praksisane i sjukeheimen var ikkje i pakt sjukepleiefaget sin argumentasjonen for at individa bør få halde fram med etablerte kroppslege vaskevanar når dei blir pleietrengjande (Førsund, 2004/1996, s. 
40). Å ta utgangspunkt i pleietrengjande sine vanar er spesielt viktig ved demens, noko over $80 \%$ av bebuarane i norske sjukeheimar har (Regjeringen, 2015). I den samanheng er det tankevekkande at sjukeheimen tilbaud dusj kvar 14. dag uavhengig av dei pleietrengjande sine vaskevanar. Då bebuarane vaks opp var det kroppsvask ved hjelp av vaskefat og klut som var vanleg (Dæhlie, 2006). Dersom ein utvida denne daglege vaskefat/klutvaskinga til full kroppsvask, gjerne supplert med ei hårvaskebalje for bebuarar som er sengeliggjande, er det ikkje sikkert at full kroppsvask ville ta lenger tid/vere meir kostbart enn dusj. Kanskje tvert om, for ved å ta utgangspunkt i vaskepraksisar som er $\mathrm{i}$ pakt med bebuaren sine vanar, kan det vere at pleiarane vil bruke mindre tid på å motivere bebuarane til å dusje og mindre tid til å handtere motstand undervegs. Men sjølv om kroppsvasken skulle bli gjort i pakt med bebuarane sine vanar, må ein rekne med at det vil ta relativt lang tid å hjelpe personar med kognitiv svikt til å vaske og stelle seg (Olsen, 1998).

\section{Førebels oppsummering}

Norma i sjukeheimen var full kroppsvask kvar 14. dag uavhengig av bebuarane sine etablerte vaskevanar. Bebuarar som var vande med dusj kvar veke måtte slutte med det, for dusj tok meir tid enn den daglege vasken av enkelte kroppsdelar ved hjelp av vaskefat og klut. Bebuarar som var vande med å vaske seg i badekar måtte slutte med det, for badekaret var fjerna frå avdelinga. Det var vanlegvis heller ikkje rom for at bebuarar som var vande med full kroppsvask ved hjelp av vaskefat og klut, fekk halde fram med slike vanar. Norma om dusj kvar 14. dag blei gjennomført sjølv om bebuarane protesterte.

\section{Kroppen kan hugse etablerte vaskevanar sjølv om hovudet sviktar}

I denne artikkelen er det gjort analysar av tilhøvet mellom dusjpraksisar i ein norsk sjukeheim og fullkroppsvaskinga som var vanleg då bebuarane vaks opp. Studien viser at det er lite samband mellom dei kroppslege vaskepraksisane som bebuarane vaks opp med og sjukeheimspraksisen med full kroppsvask kvar 14. dag. Slike vaskepraksisar braut med både pleietrengjande, pleiarar og lærebøker i sjukepleie sine normer om utvida kroppsvask ein gong i veka. Utstyret som har vore brukt ved kroppsvask har endra eg i pakt med tekniske og økonomiske omstende, og då sjukeheimsbebuarane som var involverte i denne studien vaks opp vart kroppsvask vanlegvis gjennomført ved hjelp av vaskefat og klut. Dei kroppslege praksisane som vert etablert i barndommen dannar i stor grad basis for korleis me tenkjer og handlar seinare i livet (Callewaert 1997, Halskov et al., 2008). I sjukeheimen der intervjua i denne studien blei gjort tok ikkje institusjonen utgangspunkt i dei pleietrengjande sine etablerte vaskevanar. I staden var det slik at dei pleietrengjande måtte legge vekk etablerte vaskepraksisar og innrette seg etter institusjonen sine vaskenormer når dei flytta dit. Desse brota med etablerte vaskepraksisar reagerte dei pleietrengjande negativt på. Å la vere å ta utgangspunkt i dei pleietrengjande sine etablerte vaskevanar er også eit brot med norske styresmakter sine normer for pleie av menneske med demens. Personar med demens har vanlegvis problem med korttidshukommelsen, men langtidshukommelsen kan vere intakt, så dei kan ofte vere i stand til både fortelje om og utføre praksisar dei var vande med før dei fekk demens. Det viser seg blant anna at dei som har tapt evna til å føre adekvate samtaler, kan syngje det eine verset etter det andre når dei høyrer musikk frå oppveksten (Myskja, 2017). På same vis er det mogeleg å tenkje seg at bebuarar med demens i større grad vil sette pris på og kanskje også vere i stand til å delta i vaskepraksisar som liknar på dei som dei vaks opp med. Sjølv om hovudet sviktar, kan kroppen hugse praksisar som er blitt inkorporert i familien og storsamfunnet ein veks opp i (Bourdieu, 1973, s. 72-108; Callewaert, 1997, s. 133-38). 


\section{Referansar}

Album, D. (1999). Sykdommers og medisinske spesialiteters prestisje. Tidsskrift for Den norske legeforening, 111(17), s. 2127 - 2133.

Augestad, P. (2005). Stopuret, kighullet og skoleeleven. I Larsen, K. (red.), Arkitektur, kropp og læring København: Hans Reitzels Forlag.

Boge, J. (2008). Kroppsvask i sjukepleia, Bergen:, Institutt for samfunnsmedisin, Universitetet i Bergen.

Boge, J. (2014). Funksjonaliteten til baderom i sjukeheim. Bergen: Senter for omsorgsforskning vest, https://brage.bibsys.no/xmlui/bitstream/handle/11250/278230/1/Rapport11 14 web.pdf

Boge, J., Callewaert, S. \& Petersen, K.A. (2017). The Impact of Bathroom Design on Privacy for Users with Special Needs. Ageing International, 27, 21-18, https://doi.org/10.1007/s12126-1201719311-12129.

Boge, J., \& Petersen, K.A. (2016, 18.01.). Dei som ikkje kan seie nei. Bergens Tidende, http://www.bt.no/btmeninger/kronikk/Dei-som-aldri-kan-seie-nei-310142b.html.

Boge, J. (1999). Den kroppsnære pleierelasjonen. Sjukepleievitenskap, Universitetet i Bergen.

Bourdieu, P. (1973). Tre former for teoretisk viden. I Petersen, K.A. \& Callewaert, S. (red.), Pierre Bourdieu. Centrale tekster inden for sociol ogi og kulturteori. København: Akademisk forlag.

Bourdieu, P. \& Passeron, J.C. (1999). Utbildingssystemets ideologiske funktion I Berner, B., Callewaert, C. \& Silberbrandt, H. (red.), Skola, ideologi och samhelle. Stockholm: Wahlstrøm \& Widstrand.

Callewaert, S. (1997). Habitus som internalisering af objektive forhold. I Callewaert, S. (red.), Bourdieu-studier. København: Institut for Filosofi, Pædagogik og Retorik, Københavns Universitet Amager.

Christophersen, H.O. (1975). Eilert Sundts studier av renslighetsstellet i Norge. I Sundt, E. Om renslighets-stellet i Norge. Oslo: Gyldendal.

Dæhlie, K. (2006). Vi kunne være renslige uten baderom : en studie av vann : personlig renslighet og modernisering i fjellbygda Alvdal. Oslo: Universitetet i Oslo.

Elias, N. (1989/1939). Sedernas historia. Del I av Nobert Elias civilisasjonsteori Stockholm: Atlantis.

Fjeld, W. \& Olsen, A.-G. (2000a). Kvinner og personlig hygiene. Ottestad: Habiliteringstjenesten for voksne i Hedmark.

Fjeld, W. \& Olsen, A.-G. (2000b). Menn og personlig hygiene. Ottestad: Habiliteringstjenesten for voksne i Hedmark.

Foucault, M. (1995/1976). Seksualitetens historie 1. Viljen til viten. Oslo: Pax.

Frykman, J. (1994). Hel og ren. I Frykman, J. \& O. Löfgren, O. (red.). Det kultiverte menneske. Oslo: Pax Forlag.

Fæø, S. (2016). Hjemmesykepleien - I spenningsfeltet mellom økonomi og moral. En praxeologisk studie av hjemmesykepleiens utvikling. Bergen: Institutt for global helse og samfunnsmedisin, Universitetet i Bergen, http://bora.uib.no/handle/1956/12882.

Førsund, A. J. (2004/1996). Hygiene. I Kristoffersen, N.J. (red.). Generell sykepleie, 3. Oslo: Universitetsforlaget.

Gregersen, A.-G. (2002). «Det lille ekstra»: en fenomenologisk studie av fem kvinners erfaringer når leddgikt hindrer personlig stell. Oslo: Universitetet i Oslo. 
Halskov, G., Lundin, S. \& Petersen, K.A. (2008). Homologier. I Petersen, K.A. \& Høyen, M. (red.). At sette spor på en vandring fra aquinas til Bourdieu - æresbog til Staf Callewaert. København: Hexis.

Hoffmann-Hansen, H. (2013, 4.10.). De ældre er tilbage i dansk politik. Kristeligt Dagblad.

Hofseth, C. \& Norvoll, R. (2003). Kommunehelsetjenesten - gamle og nye utfordringer: en studie av sykepleietjenesten i sykehjem og hjemmesykepleien. Trondheim: SINTEF forskningsrapport, Unimed. http://hdl.handle.net/11250/2467188.

Johnsen, T. (2004). Badeinnretninger for arbeiderbefolkningen I Eriksen, K.E. (red.), Arbeiderhistorie. Oslo: Årbok for arbeiderbevegelsens arkiv og bibliotek.

Kristoffersen, N.J. (2004/1996). Generell sykepleie 3 (7. opplag). Oslo: Universitetsforlaget.

Kropp, K. (2009). Registrantanalyse. Historisering av et felt via dokumenter. I Hammerslev, O. (red.). Refleksiv sociologi i praksis. København: Hans Reitzels forlag.

Larsen, T. A. (1999). Stellet i sykepleien: i samspillet mellom kropp og livserfaring. Troms $\varnothing$ : Avdeling for sykepleievitenskap, Universitetet i Troms $\varnothing$.

Lawler, J. (1996). Bak skjermbrettene: sykepleie, somologi og kroppslige problemer. Oslo: Gyldendal.

Lerheim, K. \& Norsk sykepleierforbund (1967). Lærebok for sykepleieskoler, Bind I: generell sykepleielære. Oslo: Fabritius \& Sønners Forlag.

Lomborg, K., Bjørn, A., Dahl, R. \& Kirkevold, M. (2005). Body care experienced by people hospitalized with severe respiratory disease. Journal of Advanced Nursing, 50(3), 2662-2271. doi:10.1111/j.1365-2648.2005.03389.x.

Lundström, I., Hermansen, R. \& Kellmer, I.-H. (1978). Om renslighet: hygienen gjennom tidene/About cleanliness: a historic perspective. Bergen: Bryggens museum.

Martinsen, K. (1984). Freidige og uforsagte diakonisser: et omsorgsyrke vokser fram, 1860-1905. Oslo: Aschehoug.

Martinsen, K. \& Wærness, K. (1991). Pleie uten omsorg? Oslo: Pax.

Moland, L. (2013). Heltid-deltid - en kunnskapsstatus. Oslo: FAFO, http://www.fafo.no/ fafo/images/pub/2013/20317.pdf

Myking, M. (2013). Palliasjon på sykehjem. Bergen: Institutt for global helse og samfunnsmedisin, Universitetet i Bergen, http://bora.uib.no/handle/1956/6813

Myskja, A. (2017). Hjertet husker det hodet glemmer; en praktisk bok om demens. Oslo: Cappelen Damm.

Nightingale, F. (1997/1860). Notater om sykepleie. Oslo: Universitetsforlaget.

Nissen, R. (2000/1877). Lærebog i Sygepleie for Diakonisser. Oslo: Gyldendal.

Olsen, R.H. (1998). Klok av erfaring?: om sansning og oppmerksomhet, kunnskap og refleksjon $i$ praktisk sykepleie. Oslo: Tano Aschehoug.

Petersen, K.A. \& Callewaert, S. (2013). Praxeologisk sygeplejevidenskab - hvad er det? København: Hexis, http://www.hexis.dk/praxeologisk-sygeplejevidenskab.pdf.

Petersen, K.A. (1993). At konstruere en teori om sygepleje. I Ramhøj, P. (red.). Overvejelser og metoder i Sundhedsforskningen. København: Akademisk Forlag.

Regjeringen. (2015). Demensplan 2020. Et mer demensvennlig samfunn. Oslo: Helse- og omsorgsdepartementet.

Schiøtz, A. (2003). Folkets helse - landets styrke, 1850-2003. Oslo: Universitetsforlaget.

Selseth, N. (1995). Stamp og dusj. Personlig hygiene i trønderlåna ca. 1900-1990. Dugnad, 3, 29-46. 
Sloane, M., Hoeffer, B., Mitchell, M. et al. (2004). Effect of Person-Centered Showering and the Towel Bath on Bathing-Associated Aggression, Agitation, and Discomfort in Nursing Home Residents with Dementia: A Randomized, Controlled Trial. Journal og the American Geriatrics Society, 52(11), 1795-1804. doi:DOI: 10.1111/j.1532-5415.2004.52501.x.

Sundt, E. (1975/1869). Om renligheds-stellet i Norge. Oslo: Gyldendal.

Sydnes, T. (2001). Centrale ideer i Florence Nightingales sykepleiefilosofi / Central ideas in Florence Nightingale's nursing philosophy. I Birkelund, R. (red.). Omsorg, kald og kamp. Personer og ideer $i$ sygepleiens historie. København: Gyldendal.

Twigg, J. (2000). Bathing, the body and community care. London: Routledge.

Ugland, R. L. (1998). Ren og velstelt Universitetet i Oslo: Oslo.

Vigarello, G. (1988). Concepts of Cleanliness:Changing Attitudes in France since the Middle Ages. Cambridge: Cambridge University Press.

Waage, H. R. (1911). Lærebok i sykepleie (2. udg.). Kristiania: I kommisjon hos H. Aschehoug \& CO.

Wolf, Z. (1993). The bath. Journal of Holistic Nursing, 11(2), 135-148, http://journals.sagepub.com/doi/pdf/110.1177/089801019301100203.

$\varnothing$ kland, B. G., \& Høiaas, K. (2000). Bare boss? : håndtering av avfall i Bergen gjennom 1000 år. Bergen: Bryggens museum. 